Review

\title{
Diversity and Evolution of Mamiellophyceae: Early-Diverging Phytoplanktonic Green Algae Containing Many Cosmopolitan Species
}

\author{
Charmaine C. M. Yung ${ }^{1,2}$, Elvira Rey Redondo ${ }^{1} \mathbb{D}$, Frederic Sanchez ${ }^{3}$, Sheree Yau ${ }^{3}$ (D) and Gwenael Piganeau ${ }^{2,3, * \mathbb{D}}$ \\ 1 Department of Ocean Science, The Hong Kong University of Science and Technology, Hong Kong SAR, China; \\ ccmyung@ust.hk (C.C.M.Y.); cereyredondo@connect.ust.hk (E.R.R.) \\ 2 Southern Marine Science and Engineering Guangdong Laboratory (Guangzhou), The Hong Kong University \\ of Science and Technology, Hong Kong SAR, China \\ 3 CNRS, UMR 7232 Biologie Intégrative des Organismes Marins (BIOM), Observatoire Océanologique, \\ Sorbonne Université, F-66650 Banyuls-sur-Mer, France; frederic.sanchez@obs-banyuls.fr (F.S.); \\ sheree.yau@obs-banyuls.fr (S.Y.) \\ * Correspondence: gwenael.piganeau@obs-banyuls.fr
}

check for updates

Citation: Yung, C.C.M.; Rey

Redondo, E.; Sanchez, F.; Yau, S.; Piganeau, G. Diversity and Evolution of Mamiellophyceae:

Early-Diverging Phytoplanktonic

Green Algae Containing Many

Cosmopolitan Species. J. Mar. Sci.

Eng. 2022, 10, 240. https://doi.org/

10.3390/jmse10020240

Academic Editor: Linda Medlin

Received: 1 December 2021

Accepted: 28 January 2022

Published: 10 February 2022

Publisher's Note: MDPI stays neutral with regard to jurisdictional claims in published maps and institutional affiliations.

Copyright: (C) 2022 by the authors. Licensee MDPI, Basel, Switzerland. This article is an open access article distributed under the terms and conditions of the Creative Commons Attribution (CC BY) license (https:// creativecommons.org/licenses/by/ $4.0 /)$.

\begin{abstract}
The genomic revolution has bridged a gap in our knowledge about the diversity, biology and evolution of unicellular photosynthetic eukaryotes, which bear very few discriminating morphological features among species from the same genus. The high-quality genome resources available in the class Mamiellophyceae (Chlorophyta) have been paramount to estimate species diversity and screen available metagenomic data to assess the biogeography and ecological niches of different species on a global scale. Here we review the current knowledge about the diversity, ecology and evolution of the Mamiellophyceae and the large double-stranded DNA prasinoviruses infecting them, brought by the combination of genomic and metagenomic analyses, including 26 metabarcoding environmental studies, as well as the pan-oceanic GOS and the Tara Oceans expeditions.
\end{abstract}

Keywords: Mamiellophyceae; biogeography; genomics; metagenomics; microalgae-virus interactions; phycoDNAvirus; evolution

\section{What Are the Mamiellophyceae? \\ 1.1. Diagnoses and Species Diversity}

DNA sequencing and molecular phylogenetic analyses are key to resolving the evolutionary relationships among unicellular eukaryotes, particularly so in microbial lineages in which observing morphological characters is challenging [1]. Morphological characters may also be misleading when they change with the life cycle of the cell or culture conditions [2]. Not surprisingly, tidying up previous taxonomic classification is an ongoing effort in most lineages, and the polyphyletic members of the "Prasinophyceae" [3,4], comprising unicellular green algae with organic scales possessing the prasinoxanthin pigment [5], are no exception. The class Mamiellophyceae was defined in 2010 based on the nuclear $18 S$, the plastidial $16 S$ and $23 S$ rDNA [6]. This novel class regroups 28 mostly marine species, with the exception of the early-branching freshwater uniflagellate lineage Monomastix, of which 25 are referenced in AlgaeBase at the time of this publication [7]. The Mamiellophyceae diagnosis, as described by Marin and Melkonian (2010), is as follows: "Eukaryotic algae, growing in water. Cells usually solitary, with 2 flagella (equal to subequal, or unequal), or a single flagellum, or lacking a flagellum. A single chloroplast, surrounded by two membranes, with chlorophylls $a$ and $b$, nearly always with prasinoxanthin. Cells sometimes with two chloroplasts. Eyespot posterior, or lacking. Cells and/or flagella covered by scales in 1-2 layers, or without scales. Scales flattened, rounded to elliptical, mostly ornamented like a spider web with concentric ribs, or uniformly reticulate. Cells and flagella lacking an inner layer of small square scales". The earliest described species of the class Mamiellophyceae are freshwater, up to 
$8 \mu \mathrm{m}$ in diameter, Monomastix species 1912 [8], and the most recently described species is the cosmopolitan marine picoeukaryote (cell diameter $<2 \mu \mathrm{m}$ ) Bathycoccus calidus (2021) [9], whereas many more novel species are poised to be discovered by joint future sampling and sequencing efforts.

\subsection{Genomics and Cryptic Species Discovery}

The democratization of genome sequencing two decades ago brought the current underestimation of species diversity within Mamiellophyceae to light. The first two strains whose genomes were sequenced were initially thought to be the same species, Ostreococcus tauri, which was described in 1934 as the smallest photosynthetic eukaryote with a cell diameter of $0.8 \mu \mathrm{m}[10,11]$. The DNA barcode used for taxonomic affiliation is generally the 1800 bp long $18 \mathrm{~S}$ rDNA sequence, and its low divergence (three single-nucleotide differences in total between the complete $18 \mathrm{~S}$ rDNA sequence of $O$. tauri and O. lucimarinus), as well as the absence of morphological differences, led to this incorrect conclusion. Wholegenome comparison revealed that these two Ostreococcus strains displayed a high level of genomic divergence, and the second strain was named Ostreococcus "lucimarinus" [12,13]. The average amino acid identity of all orthologous genes shared between these two species was indeed in concordance with the divergence observed in the genomic divergence between human and chicken [14]. This unexpected genome divergence initially observed in Ostreococcus was also observed in two strains of Micromonas pusilla [15], and one of these strains has been subsequently formally renamed as M. commoda 2016 [16]. The Micromonas genus was expanded with two additional formal species description of $M$. bravo and $M$. polaris based on the $18 \mathrm{~S}$ rDNA [17]. In a nutshell, genomics has been an eye-opener for cryptic diversity among species of the coccoid Ostreococcus and the flagellate Micromonas, and present and future genomic projects are poised to shed light on diversity within the yet poorly sequenced Mantoniella, Mamiella, Crustomastix and Dolichomastix lineages (Table 1).

\subsection{Timeline of Speciation and Population Coalescence Times}

The estimation of the timeline of speciation from molecular evolution rates poses significant challenges, and unlike diatoms [18], haptophytes [19] and dinoflagellates [20], which have fossil record from the mid-Triassic (240 Myr ago) [21], the lack of fossil data precludes the use of calibration points within Mamiellophyceae and, more generally, within the phylum Chlorophyta [22]. The divergence time between the Monomastigales and the Mamiellales (Table 1) has thus been estimated from the divergence of chloroplast genes to be 1190 [23] and 478 [24] Myr ago, with external calibration points, such as the root of Viridiplantae at $970 \mathrm{Myr}$ and the root of the land plants at $475 \mathrm{Myr}$ ago [24]. Within Mamiellales, the species divergence has been estimated to have occurred between 330 [25] and 640 [26] Myr ago. Last but not least, combining molecular evolution rates based on nuclear, mitochondrial and chloroplastic genes and external calibration points [27] such as the appearance of land plants (432 Myr), seed plant origin (355-370 Myr) and the monocot-versus-eudicot divergence (90 Myr), Slapeta et al. (2006) estimated the Micromonas divergence to be $66 \pm 10$ Myr [28]. The early-diverging Pyramimonadales and Chlorodendrophyceae lineages may be interesting to investigate further for calibration points within the phylum Chlorophyta. Indeed, it has been suggested that microfossil forms of cysts or phycomata have been identified in these two unicellular green algae lineages [29-31], whose branches diverge on either side of the Mamiellophyceae branch in the phylogenetic tree of Chlorophyta [6].

Much more recent timescales can be inferred from population genomics data by estimating the coalescence times within populations, which can be approximated by $2 \mathrm{Ne}$ ( $\mathrm{Ne}$ : effective population size) in number of generations in haploids. For example, Ne estimations are available in $O$. tauri from the complete organellar [32] and nuclear [33] genomes as $\mathrm{Ne}=3 \times 10^{7}$ and $1.2 \times 10^{7}$, respectively. The latter estimation is more accurate as a consequence of a precise estimation of the spontaneous mutation rate of the nuclear genome [34]. The founder cell of the $O$. tauri population thus likely existed $2.4 \times 10^{7}$ generations ago, and 
assuming a generation time of 2 to 3 days for these picoalgae in their natural environment, this would correspond to $\sim 135,000$ years ago. The democratization of population genomics approaches in future years is thus poised to allow short-term estimations of migration and founder events in different seas and oceanic provinces, provided the sampling effort is sufficiently wide.

\section{Genome Resources in Mamiellophyceae: From Reference Genomes to MAGs and SAGs}

High-quality genome sequences, hereafter defined by chromosome-level assemblies with curated gene annotations, rely on cultured strains. This is because the quantity and quality of DNA and RNA required for chromosome-level assemblies and transcriptomicsguided gene annotation can only be obtained from clonal cultures. With their compact haploid genomes (13 to $21 \mathrm{Mb}$ ) and their ease of culturing, the picoeukaryotic Mamiellales were the first sequenced Mamiellophyceae, and the available genome resource currently lists eight high-quality whole-genome sequences (Table 1). As all described species so far are haploid, each genome carries one sequence of the mating-type locus, a 400 to $1600 \mathrm{Kbp}$ region [35], for which two alleles have so far been described, $M T+$ and $M T-$. The sequence of both mating types is required to describe the complete diploid sequence, and this is currently only available in one species, O. tauri [33], whereas the strain identity of the alternative mating type has been recently suggested in O. mediterraneus, O. lucimarinus and $M$. commoda [35]. Nine additional genome projects are currently underway at Genoscope (France) with significantly larger estimated genome sizes (52 to $303 \mathrm{Mbp}$ ) based on cytometry estimations (Table 1).

A recent review on the state of algal genome quality and diversity provided evidence of a decline in assembly and annotation quality [36], and this trend is likely to become more pronounced with the development of single-cell sequencing approaches. The advent of multiple-cell or single-cell sorting followed by random whole-genome amplification [37] has been successful in producing, either single-cell assemblies (SAGs) of nearly complete mitochondria and chloroplasts genomes [38] or 1 to $29 \%$ of the nuclear genomes of Ostreococcus sp. RCC809, Bathycoccus sp. TOSAG49 and M. bravo [38]. Combining sequence data from four SAGs, $66 \%$ of the estimated genome assembly of a novel Bathycoccus species could be assembled [39]. Further analyses of genetic divergence between metagenome-assembled genomes (MAGs) and genomes from cultured strains are now necessary to associate a species name to "orphan" MAGs (Table 1).

Large-scale metagenomic sequencing efforts provided a substantial amount of genome sequences for picoeukaryotic Mamiellales: the Global Ocean Sampling (GOS) expedition [40] provided 20\% of the nuclear genome of Ostreococcus from the first Sargasso sea stations [41]. More recently, the Tara Oceans expedition [42] provided 10 to $28 \mathrm{Mb}$ MAGs of 8 Bathycoccus, 19 Micromonas, 2 Crustomastix, 1 Mantoniella and 4 Ostreococcus [43]. MAGs are per definition the sequencing of a population of non-clonal cells, which hampers the assembly process on polymorphic regions, such as the mating-type locus [35] or hypervariable regions [33]. However, they are paramount to estimating worldwide species diversity and distribution for as yet uncultured species and may suggest the existence of overlooked species in some oceanic regions, as suggested by the sequencing of unknown sequences among 18S rDNA metabarcoding data [44].

These genome sequence data, combined with the availability of cultures, open several research opportunities to link the genome to the ecology and biotechnological potential of these early-branching green algae. 
Table 1. Genome resources in Mamiellophyceae. Compilation of the nuclear genome resource $[9,12,15-17,43-49]$ for Mamiellophyceae species publicly available in culture from one of the following culture collections: CCAC [50], CCAP [51], NCMA (https: / /ncma.bigelow.org/, accessed on 5 October 2021), NIES (https://mcc.nies.go.jp/, accessed on 5 October 2021), RCC [52], SAG (https://www.uni-goettingen.de/, accessed on 5 October 2021) or UTEX [53]. Orphan genome sequences from metagenomes yet to be affiliated to an existing or to a novel species for which a unique $18 \mathrm{~S}$ rDNA sequence or a $>10 \mathrm{Mb}$ assembly is publicly available are colored in blue. *: genome size estimation based on cytometry.

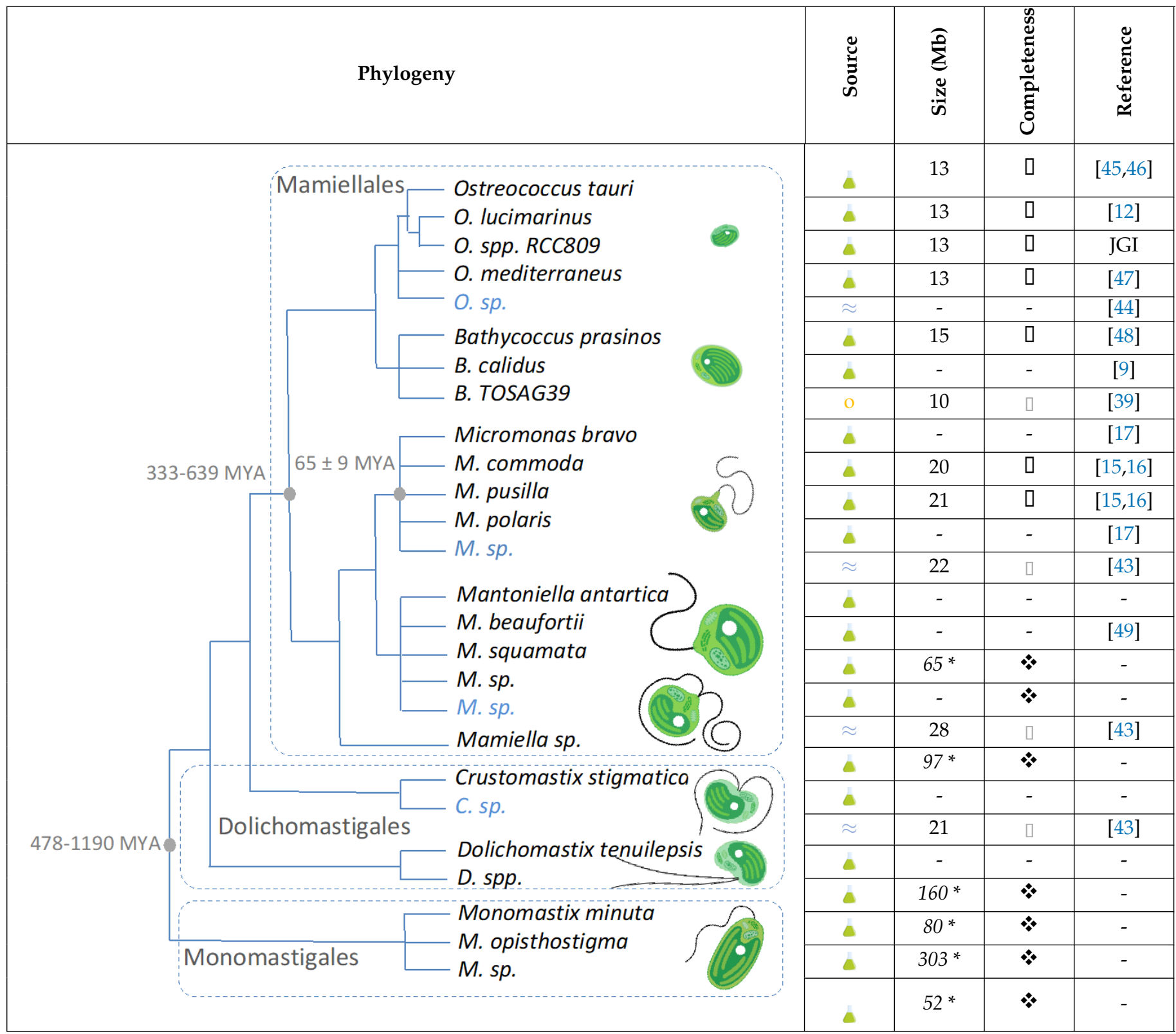

strain available in culture; $\circ$ single-cell assembled genome; $\approx$ metagenomic origin; $\square$ complete genome sequence with annotation; $\square$ genome assembly available; genome sequencing in progress; - no data.

\section{Where Are the Mamiellophyceae in the Sunlit Ocean?}

\subsection{Metabarcoding Insights}

Metabarcoding has been routinely employed to characterize microbial communities and can contribute to unraveling the vast diversity of unknown phytoplanktonic eukaryotes [54]. This technique involves extracting DNA from environmental specimens and 
amplifying DNA metabarcodes, such as the 16S/18S rRNA gene, followed by sequencing [55]. Sequenced data are then quality-filtered, clustered into operational taxonomic units (OTUs) or amplicon sequence variants (ASVs) and further used for taxonomic and ecological analyses. This approach has allowed the discovery of many marine microbes that had not previously been isolated, including diverse green algal species [44]. An increasing number of studies have investigated the eukaryotic microbial communities in the global ocean, e.g., [44,56-60]. Many metabarcoding studies have found Mamiellophyceae to be the important group in the dataset from tropical to polar waters (Figure 1, Supplementary Table S1). Mamiellophyceae were also detected in brackish water and freshwater lake, where the salinity ranged from 0 to $7 \mathrm{~g} \cdot \mathrm{L}^{-1}[61,62]$. Most of these studies used the $18 \mathrm{~S} \mathrm{~V} 4$ or V9 region as the barcode, and a few targeted the plastid 16S [63] or 28S [56]. Nevertheless, the focus of these studies was not Mamiellophyceae but the overall eukaryotic phytoplankton diversity, and thus, many of them did not examine the abundance of different Mamiellophyceae strains at the genus or clade level. In general, the studies showed that Mamiellophyceae are ubiquitous in the ocean, particularly in coastal waters, whereas no further information about the niche specialization among the different genera and strains was available.

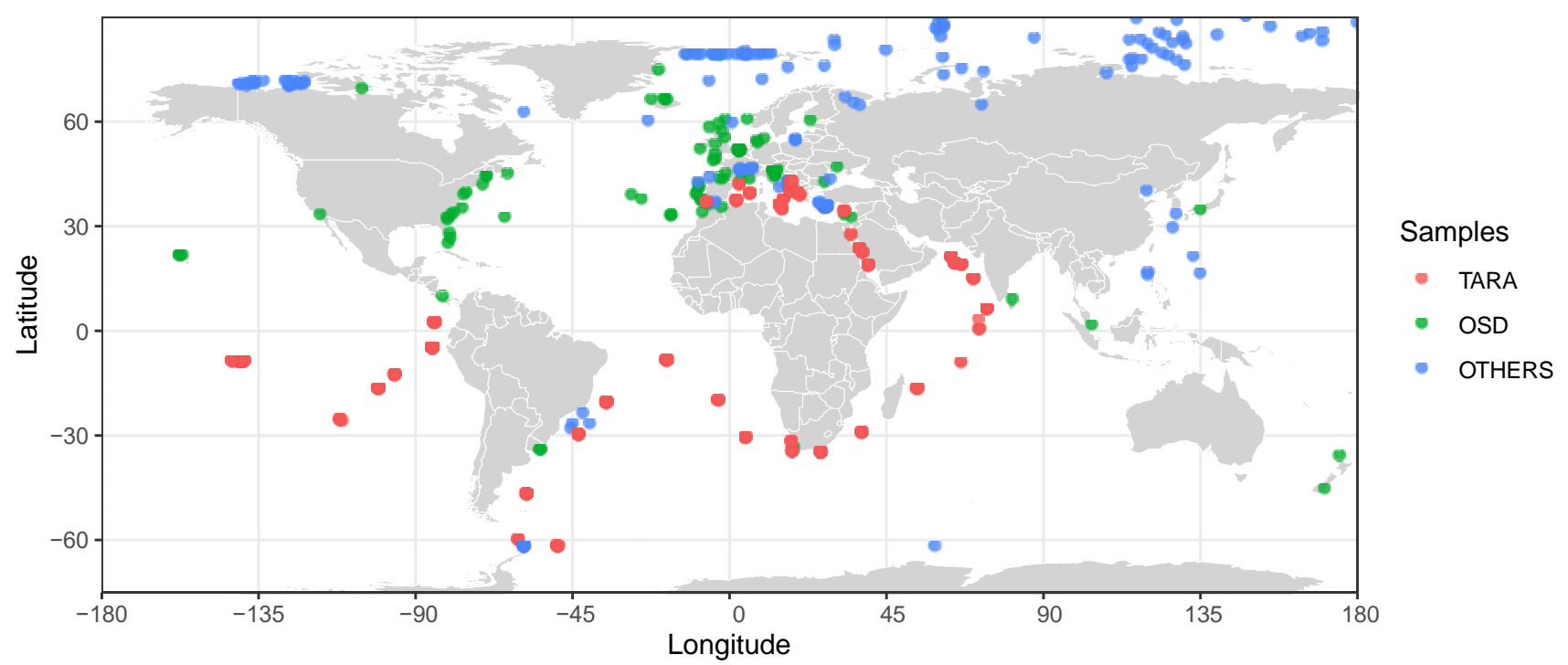

Figure 1. Worldwide distribution of Mamiellophyceae from 26 metabarcoding studies (Supplementary Table S1).

Two global-scale surveys involved the usage of the Ocean Sampling Day (OSD) [45] and the Tara Oceans expedition [57,60] metabarcoding datasets. Mamiellophyceae were found at most OSD stations (143 mostly coastal stations), representing $55 \%$ of the Chlorophyta reads. The distribution of the four most-represented genera Micromonas, Ostreococcus, Bathycoccus and Mantoniella was further examined. Each of them had a unique oceanic distribution pattern, indicating specific adaptation to different ecological niches. Interestingly, Mantoniella beaufortii and baffinensis were only detected in the Arctic Ocean water but were not found in the Southern Ocean or off Antarctica [49], even though the environmental conditions of the North and South Polar waters should be similar. Whereas these data suggested that these two Mantoniella species were restricted to polar Arctic regions, $\mathrm{Mi}$ cromonas polaris was present in both Arctic water and the Southern Ocean [64]. However, it remains uncertain why the Mantoniella and Micromonas species have a different distribution in the polar regions. On the other hand, the Tara Oceans data suggested that the diversity of Mamiellophyceae assemblages is primarily determined by geographical provenance and distinct taxonomic composition between Mamiellophyceae coastal and open-ocean communities [45]. However, most of the OSD samples were collected in coastal waters, and 
thus more investigations are required to assess the taxonomic makeup of Mamiellophyceae in the open ocean.

In addition to large ocean expeditions and global sampling strategies, small-scale metabarcoding surveys have also unraveled previously unexplored distribution and diversity of Mamiellophyceae. Studies targeting Arctic waters observed the co-existence of several Micromonas species, whereas M. polaris dominates at high latitudes beyond $72^{\circ} \mathrm{N}$ [56]. O. tauri, O. mediterraneus and O. lucimarinus, which are believed to be more prevalent in warmer waters, were also observed at high latitudes beyond $65^{\circ} \mathrm{N}$, even though at a low relative abundance [56]. This suggests that smaller-scale surveys can also broaden our knowledge about the distribution of Mamiellophyceae, particularly in marine environments. Further, studies on Mamiellophyceae from tropical waters in the Philippines found that different Micromonas and Ostreococcus clades were present, but the majority of the sequences identified were from uncultured clade E [65], which are also prevalent in the Mediterranean Sea and coastal warm temperate sites in the Atlantic [45]. A potential novel Ostreococcus clade was also observed in the same study, suggesting that more sampling effort in understudied regions is expected to discover more previously undescribed Mamiellophyceae diversity. In addition, various studies have attempted to link the diversity of Mamiellophyceae with environmental conditions. Temperature, salinity and nutrients are suggested to be the important drivers determining the dominant populations of Mamiellophyceae [65-67]. The increase in temperature toward summer was associated with lower Mamiellophyceae abundance in tropical waters [65]. In the Red Sea, Micromonas was found to outcompete Ostreococcus and Bathycoccus in the more nutrient-limited conditions but was replaced when more nutrients were available [66]. The biodiversity of Mamiellophyceae has also been examined with the 28S rRNA metabarcoding, but the limited reference sequences from described species obstruct species identification with this marker [56].

As the metabarcoding data are reporting more new environmental clades of Mamiellophyceae, there is an urge to obtain more information about these clades and determine whether they are novel species. For example, with more knowledge about their geographical distribution patterns, we can target specific environments to isolate these environmental clades and determine their physiological preferences, such as temperature and nutrient requirements. Other approaches for investigating clades that are difficult to isolate in culture would be through metagenomics, flow cytometry and single-cell genomics.

\subsection{Metagenomics and Genome-Informed Biogeography}

The metabarcoding approach depends on the specificity and accuracy of the universal phylogenetic marker genes, as well as the availability of comprehensive taxonomy reference databases, such as SILVA and PR2 databases [68,69]. It has been demonstrated that commonly used metabarcoding primers display known phylogenetic bias [70], and the taxonomic marker genes have limited phylogenetic resolutions [71]. For instance, the V9 region of the 18S rRNA gene is identical in all known species within Ostreococcus and Bathycoccus [57].

To complement the knowledge gathering from metabarcoding studies, metagenomics is a crucial tool to discover and quantify the abundance of microorganisms when their genomes are available. Culture genomes, single-cell genomes and meta-genome-assembled genomes (Table 1) are precious resources to recover their biogeographic distribution patterns. Metagenomic read recruitment based on available genome resources can be linked to environmental variables and thus infer niche specialization. For example, analysis of Tara Oceans metagenomes from 122 stations using the two Bathycoccus genomes (Bathycoccus prasinos RCC1105 in culture and Bathyococcus sp. TOSAG39-1 from metagenome assembly) show that the Bathycoccus species that have identical 18S rRNA genes display distinctive biogeographic niches with respect to depth [39]. A recent study used six Mamiellophyceae reference genomes, including Bathycoccus prasinos RCC1105 and Bathyococcus sp. TOSAG391, M. commoda RCC299 and M. pusilla CCMP1545 and O. RCC809 and O. lucimarinus strain 
CCE9901, to recruit metagenomic sequence reads collected from 80 sites from the Tara Oceans expedition [72]. The study showed that the distribution of Mamiellophyceae is associated with different temperatures, i.e., O. lucimarinus, B. prasinos and M. pusilla were found in colder waters, whereas Ostreococcus sp. RCC809, Bathycoccus sp. TOSAG39-1 and $M$. commoda were more abundant in warmer waters. It also systematically detected two candidate mating types of O. lucimarinus [35] together.

The type of genome-based approach provides novel insights into the biogeography of Mamiellophyceae and raises novel hypotheses about their life cycle and ecology. With more available metagenomes and reference genomes, we can better understand the understudied Mamiellophyceae lineages in a wide range of marine environments. Moreover, we can better understand how the environmental drivers structure the Mamiellophyceae distribution as well as their interactions with other species and eukaryotic viruses.

\section{Can Viruses of Mamiellophyceae Inform Their Diversity and Evolution?}

\subsection{Prasinoviruses Are Key Regulators of Mamiellales Populations}

The first algal virus isolated was a virus infecting Micromonas pusilla in 1979. Termed $\mathrm{MpV}$ for Micromonas pusilla virus, its isolation came almost two decades after the first description of its host species. Although this first $\mathrm{MpV}$ was subsequently lost from culture [73], based on its morphology [74], it was almost certainly a prasinovirus. These are lytic viruses with dsDNA genomes of $\sim 200 \mathrm{~kb}$ and icosahedral virions measuring $\sim 120 \mathrm{~nm}$ in diameter bearing an internal membrane. It took another decade for prasinoviruses to be reisolated, showing them to be as widespread as their hosts [73]. Moreover, prasinoviruses were shown to contribute $10-25 \%$ of the mortality of Micromonas species, which was of a similar magnitude as grazing $[75,76]$. Metagenomic surveys indicate that prasinoviruses are ubiquitous and among the most abundant dsDNA viruses in marine waters [77,78].

The genus Prasinovirus was recognized by the ICTV (International Committee of the Taxonomy of Viruses) in 1938 [79] and contains two formally recognized species: Micromonas pusilla virus SP1 (MpV-SP1) and Ostreococcus tauri virus 5 (OtV5). They are in the family Phycodnaviridae (algae-infecting DNA viruses) and phylum Nucleocytoviricota (from the unofficial name NCLDV—Nuclear Cytoplasmic Large DNA Viruses), which are the most common viruses infecting eukaryotic algae [80]. Despite there being only two recognized species, it is clear numerous virus isolates are species of Prasinovirus based on the phylogeny of the conserved DNA polymerase B (PolB) (Figure 2), as well as virion morphology. Whereas the name prasinovirus is in reference to their "prasinophyte" hosts, all prasinovirus isolates infect only Mamiellales (Table 1). As prasinoviruses tend to be species-specific, they have traditionally been named for the species they infect, which has led to incongruencies between the virus and host names, as hosts have been revised by molecular taxonomy. This is especially the case for the viruses of Micromonas, of which many have been described as infecting Micromonas pusilla before the separation of M. pusilla into six proposed species [17]. Here, we report the most up-to-date name of the host species on which the virus was isolated, while retaining the virus name as published (Table 2, Figure 2).

Table 2. Host species and collection sites of isolated prasinoviruses.

\begin{tabular}{ccccccc}
\hline Host Genus & Host Species & Host Clade * & $\begin{array}{c}\text { Genome- } \\
\text { Sequenced } \\
\text { Viruses }\end{array}$ & $\begin{array}{c}\text { Prasinovirus } \\
\text { Isolates }\end{array}$ & Isolation Sites & References \\
\hline \multirow{3}{*}{ Bathycoccus } & prasinos & BI & BpV1, BpV2 & 9 & $\begin{array}{c}\text { Mediterranean Sea, } \\
\text { North Atlantic }\end{array}$ & [81,82] \\
& calidus & BII & $\begin{array}{c}\text { BIIV-1, BIIV-2, } \\
\text { BIIV-3 }\end{array}$ & 3 & North Atlantic & [9] \\
\hline
\end{tabular}


Table 2. Cont.

\begin{tabular}{|c|c|c|c|c|c|c|}
\hline Host Genus & Host Species & Host Clade * & $\begin{array}{l}\text { Genome- } \\
\text { Sequenced } \\
\text { Viruses }\end{array}$ & $\begin{array}{l}\text { Prasinovirus } \\
\text { Isolates }\end{array}$ & Isolation Sites & References \\
\hline \multirow{5}{*}{ Micromonas } & commoda & A.ABC.12 & $\mathrm{MpV}-12 \mathrm{~T}$ & 31 & North Atlantic, North Sea & {$[83,84]$} \\
\hline & bravo & B.E.3 & - & 7 & $\begin{array}{l}\text { Mediterranean Sea, } \\
\text { North Atlantic }\end{array}$ & {$[84,85]$} \\
\hline & pusilla & C.D.5 & $\begin{array}{l}\text { MpV-SP1, } \\
\text { MpV-P1 }\end{array}$ & 35 & $\begin{array}{c}\text { Mediterranean Sea, North } \\
\text { Atlantic, North Pacific, } \\
\text { North Sea }\end{array}$ & {$[73,83,84]$} \\
\hline & polaris & $\mathrm{Ea}$ & - & 4 & $\begin{array}{l}\text { Barents and Greenland } \\
\text { Seas (Spitsbergen) }\end{array}$ & [86] \\
\hline & candidate sp. 2 & unknown & MpV1 & 16 & $\begin{array}{l}\text { Mediterranean Sea, } \\
\text { North Atlantic }\end{array}$ & {$[84,87]$} \\
\hline $\begin{array}{l}\text { Unclassified } \\
\text { Mamiellales }^{+}\end{array}$ & unknown & unknown & - & 11 & $\begin{array}{l}\text { North Atlantic } \\
\text { (English Channel) }\end{array}$ & {$[84,87]$} \\
\hline \multirow{4}{*}{ Ostreococcus } & lucimarinus & A & $\begin{array}{l}\text { OlV1, OlV2, OlV3, } \\
\text { OlV4, OlV5, OlV6, } \\
\text { OlV7 }\end{array}$ & 27 & $\begin{array}{l}\text { Mediterranean Sea, } \\
\text { North Atlantic, North } \\
\text { Pacific, South Pacific }\end{array}$ & {$[88,89]$} \\
\hline & sp. & B & OtV2 & 1 & North Atlantic & [90] \\
\hline & tauri & C & OtV1, OtV5, OtV6 & 54 & $\begin{array}{l}\text { Mediterranean lagoon, } \\
\text { North Atlantic }\end{array}$ & [91-94] \\
\hline & mediterraneus & $\mathrm{D}$ & OmV1, OmV2 & 7 & Mediterranean lagoon & {$[47,81]$} \\
\hline
\end{tabular}

${ }^{*}$ Clade names sensu [17]. ${ }^{\dagger}$ Classified in [87] as Micromonas RCC2485 clade A and identified as related to unknown Mamiellales sp. RCC391 [6].

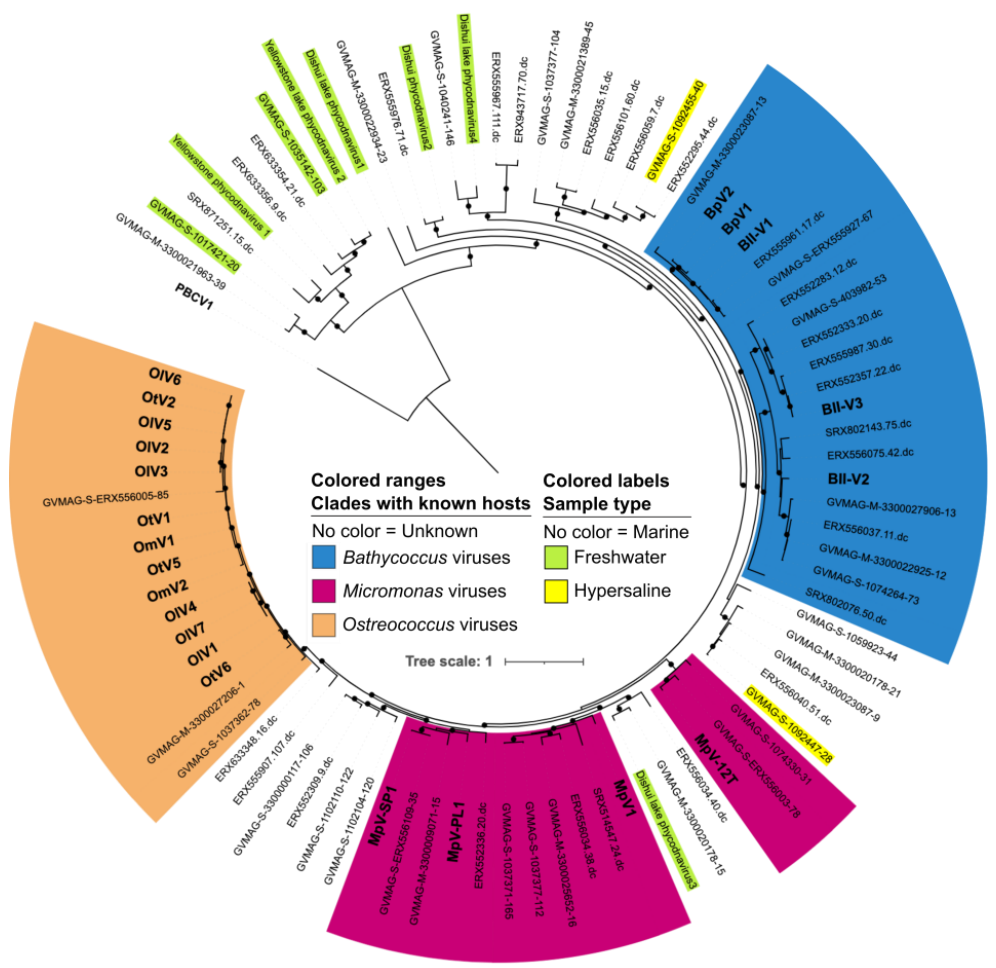

Figure 2. Diversity of prasinovirus isolates and MAGs based on the phylogeny of DNA polymerase B protein sequences. Virus names in bold are prasinovirus isolates with sequenced genomes, except PBCV1 (Paramecium bursaria chlorella virus 1), which is the representative freshwater chlorovirus used as the sister taxon to root the tree. All other sequences are MAGs from recent studies classed as "Prasinoviridae" [95]. Protein sequences were aligned in MAFFT (v.7.313) with the L-INS-i algorithm [96], positions with $>50 \%$ gaps were trimmed in Goalign (v0.3.2) [97], and the maximumlikelihood ( $\mathrm{LG}+\mathrm{F}+\mathrm{R} 4$ model) phylogeny and bootstrapping (1000 replicates) were calculated in IQ-TREE (v.2.0.6) [98] and visualized in iTOL (v6) [99]. Black nodes show bootstrap support $>80 \%$. 
The only other type of virus infecting Mamiellales has a dsRNA genome (family Reoviridae), which infects Micromonas commoda and was designated Mimovirus MpRV for M. pusilla RNA virus [100] (where the host strain LAC38 was later reclassified [86]). Nonetheless, as virus isolation efforts on Mamiellales strains consistently retrieve prasinoviruses (Table 2), this suggests that they are the most common viruses of Mamiellales.

\subsection{Host Range of Available Isolated Prasinoviruses}

Currently, there are 22 prasinovirus isolates with genome sequences available (Table 2). For Micromonas and Ostreococcus, which have multiple hosts and virus strains are available, two patterns in host-virus interactions are evident. Within a viral clade, host range exists on a continuum from "specialist" viruses, capable of infecting only a single host strain, to "generalist" viruses, capable of infecting multiple host strains in a "nested" or hierarchical interaction network. Between viral clades, there is little cross-infection of algae outside the host species group, which is evident as a "modular" host-virus interaction network $[84,87,101,102]$. The broadest host range prasinovirus strains so far observed can infect across three species of Micromonas [86] and Ostreococcus [103]. All isolates thus far have been reported to infect only a single genus. However, a reanalysis of host strain RCC2485 that was described as Micromonas clade A [87] indicates it is likely a new genus corresponding to the unknown Mamiellales (RCC391) that diverged between Mamiella and the Mantoniella / Micromonas clade in its 18S rRNA phylogeny [6]. As these viruses isolated on RCC2485 were able to infect Micromonas bravo, they suggest prasinoviruses thought to strictly infect species from the Micromonas genus may in fact infect a wider range of the related genera Mamiella and Mantoniella.

There is a strong correlation between the PolB phylogeny and diversity of isolated prasinoviruses and their host diversity (Figure 2). Bathycoccus-infecting and Ostreococcusinfecting prasinoviruses so far identified fall within single clades (Figure 2). Conversely, Micromonas is the most species-rich genus, and Micromonas-infecting viruses have the most genetic diversity, being separated into at least two distinct clades (Figure 2). Within these genus-specific clades, some species specificity is evident; for example, O. lucimarinus viruses are all from one of two well-defined clades [89], although it remains to be seen with wider isolation efforts if these tendencies remain. In addition, host species with overlapping habitats, such as O. tauri and O. mediterraneus, as well as O. lucimarinus and Ostreococcus sp. clade B, have viruses from the same prasinovirus clade (Figure 2). Similarly, prasinoviruses appear to infect across species that are sympatric; for example, the most frequent cross-species infecting Micromonas viruses are between M. commoda and M. pusilla [84]. Overall, this suggests cospeciation between prasinoviruses and Mamiellales is occurring, punctuated by some host-species switching/expansion events. The largest potential host switch in the known prasinovirus lineages is the earlier divergence of Micromonas in the Mamiellales phylogeny (Table 1) compared to the earlier divergence of Bathycoccus viruses in the Prasinovirus PolB tree (Figure 2).

Metagenomic surveys have shown that prasinoviruses are present in diverse aquatic environments and comprise numerous clades for which there are no isolated representatives (Figure 2). By far the most prasinovirus diversity explored comes from marine metagenomes with Bathycoccus-infecting and Micromonas-infecting clades seeming to be the most prevalent and diverse. This is in line with the wider distribution of these species in open-ocean environments. Prasinovirus MAGs have been retrieved from freshwater lakes, Dishui Lake (Shanghai, China) $[103,104]$ and a lake from Yellowstone National Park (USA) [105], which tend to form "freshwater" prasinovirus clades albeit mixed with sequences from marine environments. Similarly, there are prasinoviruses retrieved from hypersaline lakes that form clades with marine sequences without cultured representatives. Given the high specificity of isolated prasinoviruses to Mamiellophyceae, it is likely these unknown prasinoviruses also infect Mamiellophyceae species. We can infer that MAGs within the Bathycoccus-infecting, Micromonas-infecting and Ostreococcus-infecting clades infect these genera, although it is possible that yet-to-be-discovered viruses within these 
clades infect other genera. Likely hosts for these unknown prasinovirus clades are other genera of Mamiellophyceae with no known viruses, such as Crustomastix, Mantoniella and Mamiella. The hosts of prasinovirus clades from lakes may therefore be the freshwater genus Monomastix, although it is clear there is no strict demarcation between prasinovirus clades and environmental conditions, and likely estuarine clades can tolerate a broad range of salinities.

The broader diversity in prasinovirus MAGs compared to isolates is likely caused by a bias in isolation efforts. First, only a handful of Mamiellales host strains have been used to isolate viruses. It may well be the case that the unknown marine prasinovirus clades simply infect other strains of Mamiellales outside the most studied representative strains. Second, the vast majority of prasinoviruses have been isolated from coastal waters. Prasinovirus MAGs, on the other hand, have been sampled from a wider range of environments, and the marine samples include far more open-ocean sites, showing how the cultivable prasinovirus diversity is strongly biased to coastal areas. Future isolation efforts therefore should utilize a broader range of host strains and environments to improve the represented diversity of isolated prasinoviruses.

\subsection{Do Prasinoviruses Co-Occur with Their Host?}

The availability of cultured Mamiellales-prasinovirus systems and the specificity of their interaction opened an avenue to test if prasinoviruses co-occur with their hosts and to what extent they are related to the host population demise. A culture-based strategy to do this is to obtain a time course of infectious viruses by plaque assays or end-point dilutions, ideally coupled with simultaneous measures of the algal population dynamics (by flow cytometry, fluorescence in situ hybridization (FISH) or serial dilution). This has been done for Micromonas [76,84,86,101,106] and Ostreococcus [93], often showing prasinoviruses to be present year-round. For Micromonas, cycling between host clades indeed coincided with the succession of prasinoviral clades [84]. However, no clear association was found between O. tauri and OtV abundance [93], as specific quantification of these tiny host cells was challenging.

The wealth of metagenomic data and sequencing databases permits a new lens to determine if prasinoviruses are important regulators of Mamiellales. Three metagenomic studies confirm the strong co-occurrence between prasinoviruses and Mamiellophyceae $[82,107,108]$ in the marine environment. Moreover, there was also a significant link between free prasinoviruses and carbon export [109]. At a specific taxonomic level, a global metagenomic survey of Bathycoccus species and Bathycoccus-infecting viruses [9] has revealed a tight co-occurrence between host and prasinovirus clades in 29/31 samples. VirusFISH, whereby viruses and hosts are marked by specific DNA probes, permitted the quantification of infected and non-infected cells showing between $0-60 \%$ of Ostreococcus cells in the natural population in the Cantabrian Sea were infected over the year but only in surface water [110]. These studies pave the way for future work on species-level cooccurrences of Mamiellales and prasinoviruses at global and local scales, as much remains to be discovered about the extent of viral control on phytoplankton dynamics.

\section{Conclusions and Perspectives}

Compared to prokaryotic phytoplankton, there are still major gaps in our understanding of the biogeography and ecology of eukaryotic green algae because of a major technical challenge in characterizing eukaryotic genomes. The size and complexity of eukaryotic genomes make it more challenging and will need further innovation in bioinformatics algorithms and/or sequencing technologies. In addition, there are only limited algal reference genomes available for mapping metagenomic and metatranscriptomic data, which would require more sequencing efforts.

The metagenomic analyses of microbial communities continue to evolve by technological improvements in DNA and RNA sequencing. Long-read sequencing technologies $(>10 \mathrm{~kb})$ can improve genome assemblies and assignment of taxonomy and func- 
tion [111,112]. As long-read sequencing becomes cheaper and more accurate, it will become easier to retrieve novel metagenome-assembled genomes from the global metagenomic data to study population dynamics of the uncultured Mamiellophyceae. However, there is an urgent need to expand high-quality annotation databases so that we can understand the mechanisms of the green algal functions.

Other sequencing platforms are also emerging, such as the high-throughput chromosome conformation capture (Hi-C) method, a DNA proximity technique that displays great potential to overcome the bottlenecks in the metagenomic binning approach [113]. Hi-C has been used extensively in medical research to determine the scaffolding of chromosomes. When applied to metagenomics (metagenomic $\mathrm{Hi}-\mathrm{C}$ ), the $\mathrm{Hi}-\mathrm{C}$ technique is combined with traditional shotgun sequencing to retrieve high-quality MAGs from a single sample [114]. The Hi-C method involves crosslinking DNA in a live population using formaldehyde to hold DNA shape in place. Next, a series of standard molecular techniques are performed to label the parts of DNA that are near one another, physically join them, concentrate them and cut the DNA into small pieces. This results in short DNA sequences that are composed of two different regions of DNA which were physically close to each other in the live cell. In this way, a forward read and a reverse read will be from two different parts of one or more chromosomes which are linked together in a probabilistic manner, dependent on proximity within the live cell, as sequences are indeed closest when they occupy the same cell. It enables the identification of DNA molecules that are physically co-located near one another within a cell through next-generation sequencing. Hi-C sequencing has also been recently applied to artificial metagenomes [115] and recently to natural metagenomes [116] to assemble genomes of different species and identify the structure of chromosomes, the presence of plasmids within cells and potentially host and viral interactions [117]. Other molecular biology techniques, such as proximity ligation, have recently been applied to marine water samples to identify novel virus-host associations [118]. With this kind of host non-specific ligation method compared to the traditional host-virus isolation and infection method, there is hope to identify uncultured Mamiellophyceae host and viral associations in the natural environment and link environmental functions to taxonomic units.

Whereas metagenomics can inform a marine microbial community's metabolic and functional capacity, it cannot differentiate between expressed and non-expressed genes. The expression level of the genes may vary because of different physiological statuses in response to the surrounding environment. Thus, metagenomics fails to envisage the in situ metabolic activity. On the other hand, metatranscriptomics enables the analysis of the relative abundance of transcripts from genes expressed in the environment and, therefore, better delineates the ongoing ecological processes in response to nutrient availability, diel variability and harmful algal bloom formation [119-121]. In addition, the integration of metagenomic and metatranscriptomic data can quantify levels of gene expression based on gene abundance and provide important insights. For example, the abundances of genes and transcripts from global ocean microbial communities at the species level were used to determine the changes of biogeochemical processes involved in photosynthesis, carbon cycling and nitrogen cycling across latitude and depth [122]. However, such studies have yet to be conducted targeting the Mamiellophyceae. The rapid increase in metatranscriptome studies in the ocean and the more adequate algal reference genomes can facilitate these functional metatranscriptomic analyses. Thus, we can obtain novel insights into the active algal members, their gene expression and metabolic pathways across different environmental conditions.

Although a multi-omics-based ecological analysis of the marine phytoplankton community can reveal the relation between physicochemical factors and the dynamics of eukaryotic algae and viruses, cultivation of eukaryotic algae is still the most reliable approach of validating the ecological hypotheses generated from the field research. Moreover, establishing stable cultures facilitates biotechnology applications, including novel bioactive compound discovery and production, which are rarely explored in the Mamiellophyceae. 
Supplementary Materials: The following data are available online at https:/ /www.mdpi.com/ article/10.3390/jmse10020240/s1, Table S1: Metabarcode identity, reference and GPS coordinates included in Figure 1.

Author Contributions: Conceptualization, writing and editing: G.P., C.C.M.Y. and S.Y. Cytometry genome size estimations: F.S. Compilation of metabarcoding and metagenomic analyses: E.R.R. All authors have read and agreed to the published version of the manuscript.

Funding: This research was funded by the Hong Kong Branch of Southern Marine Science and Engineering Guangdong Laboratory (Guangzhou), grant number SMSEGL20SC02.

Institutional Review Board Statement: Not applicable.

Informed Consent Statement: Not applicable.

Data Availability Statement: This is a review of previously published data.

Acknowledgments: We would like to thank all members of the Genophy group and the Tara Oceans consortium for stimulating discussions. We are grateful to the BIOPIC cytometry platform for access to equipment and software and Valerie Domien from the SI service of the OOB for help with Table 1.

Conflicts of Interest: The authors declare no conflict of interest.

\section{References}

1. Boenigk, J.; Ereshefsky, M.; Hoef-Emden, K.; Mallet, J.; Bass, D. Concepts in Protistology: Species Definitions and Boundaries. Eur. J. Protistol. 2012, 48, 96-102. [CrossRef] [PubMed]

2. Rose, D.; Cox, E. What Constitutes Gomphonema Parvulum? Long-Term Culture Studies Show That Some Varieties of G. Parvulum Belong with Other Gomphonema Species. Plant Ecol. Evol. 2014, 147, 366-373. [CrossRef]

3. Moestrup, Ø.; Throndsen, J. Light and Electron Microscopical Studies on Pseudoscourfieldia marina, a Primitive Scaly Green Flagellate (Prasinophyceae) with Posterior Flagella. Can. J. Bot. 1988, 66, 1415-1434. [CrossRef]

4. Steinkötter, J.; Bhattacharya, D.; Semmelroth, I.; Bibeau, C.; Melkonian, M. Prasinophytes form independent lineages within the Chlorophyta: Evidence from ribosomal RNA sequence comparisons. J. Phycol. 1994, 30, 340-345. [CrossRef]

5. Foss, P.; Guillard, R.R.L.; Liaaen-Jensen, S. Prasinoxanthin: A Chemosystematic Marker for Algae. Phytochemistry 1984, 23, 1629-1633. [CrossRef]

6. Marin, B.; Melkonian, M. Molecular Phylogeny and Classification of the Mamiellophyceae Class. Nov. (Chlorophyta) Based on Sequence Comparisons of the Nuclear- and Plastid-Encoded RRNA Operons. Protist 2010, 161, 304-336. [CrossRef]

7. Guiry, M.D.; Guiry, G.M. AlgaeBase; World-Wide Electronic Publication, National University of Ireland: Galway, Ireland, 2021.

8. Scherffel, A. Zwei Neue, Trichocystenartige Bildungen Führende Flagellaten. Arch. Protistenkd. 1912, $27,94-128$.

9. Bachy, C.; Yung, C.C.M.; Needham, D.M.; Gazitúa, M.C.; Roux, S.; Limardo, A.J.; Choi, C.J.; Jorgens, D.M.; Sullivan, M.B.; Worden, A.Z. Viruses Infecting a Warm Water Picoeukaryote Shed Light on Spatial Co-Occurrence Dynamics of Marine Viruses and Their Hosts. ISME J. 2021, 15, 3129-3147. [CrossRef]

10. Courties, C.; Vaquer, A.; Troussellier, M.; Lautier, J.; Chrétiennot-Dinet, M.J.; Neveux, J.; Machado, C.; Claustre, H. Smallest Eukaryotic Organism. Nature 1994, 370, 255. [CrossRef]

11. Chrétiennot-Dinet, M.-J.; Courties, C.; Vaquer, A.; Neveux, J.; Claustre, H.; Lautier, J.; Machado, M.C. A New Marine Picoeucaryote: Ostreococcus tauri Gen. et Sp. Nov. (Chlorophyta, Prasinophyceae). Phycologia 1995, 34, 285-292. [CrossRef]

12. Palenik, B.; Grimwood, J.; Aerts, A.; Rouze, P.; Salamov, A.; Putnam, N.; Dupont, C.; Jorgensen, R.; Derelle, E.; Rombauts, S.; et al. The Tiny Eukaryote Ostreococcus Provides Genomic Insights into the Paradox of Plankton Speciation. Proc. Natl. Acad. Sci. USA 2007, 104, 7705-7710. [CrossRef] [PubMed]

13. Jancek, S.; Gourbière, S.; Moreau, H.; Piganeau, G. Clues about the Genetic Basis of Adaptation Emerge from Comparing the Proteomes of Two Ostreococcus Ecotypes (Chlorophyta, Prasinophyceae). Mol. Biol. Evol. 2008, 25, 2293-2300. [CrossRef] [PubMed]

14. Piganeau, G.; Eyre-Walker, A.; Jancek, S.; Grimsley, N.; Moreau, H. How and Why DNA Barcodes Underestimate the Diversity of Microbial Eukaryotes. PLoS ONE 2011, 6, e16342. [CrossRef] [PubMed]

15. Worden, A.Z.; Lee, J.H.; Mock, T.; Rouze, P.; Simmons, M.P.; Aerts, A.L.; Allen, A.E.; Cuvelier, M.L.; Derelle, E.; Everett, M.V.; et al. Green Evolution and Dynamic Adaptations Revealed by Genomes of the Marine Picoeukaryotes Micromonas. Science 2009, 324, 268-272. [CrossRef]

16. Van Baren, M.J.; Bachy, C.; Reistetter, E.N.; Purvine, S.O.; Grimwood, J.; Sudek, S.; Yu, H.; Poirier, C.; Deerinck, T.J.; Kuo, A.; et al. Evidence-Based Green Algal Genomics Reveals Marine Diversity and Ancestral Characteristics of Land Plants. BMC Genom. 2016, 17, 267. [CrossRef]

17. Simon, N.; Foulon, E.; Grulois, D.; Six, C.; Desdevises, Y.; Latimier, M.; Le Gall, F.; Tragin, M.; Houdan, A.; Derelle, E.; et al. Revision of the Genus Micromonas Manton et Parke (Chlorophyta, Mamiellophyceae), of the Type Species M. pusilla (Butcher) 
Manton \& Parke and of the Species M. commoda van Baren, Bachy and Worden and Description of Two New Species Based on the Genetic and Phenotypic Characterization of Cultured Isolates. Protist 2017, 168, 612-635. [CrossRef]

18. Villac, C.; Harwood, D.; Wittkowski, J.; Medlin, L.K. Diatom Evolution from Fossils to Modern from the Benthos into the Plankton. JMSE, 2022; in press.

19. Henderiks, J.; Strum, D.; Supraha, L. Evolutionary Rates in the Haptophyta: Exploring Molecular and Phenotypic Diversity. JMSE, 2022; in press.

20. Riding, J.B.; Fensome, R.A.; Dale, B.; Gobillard, M.-O.; Medlin, L.K. An Overview of Dinoflagellate Evolution with Comments on Their Adaptation to the Plankton. JMSE, 2022; in press.

21. Falkowski, P.G.; Katz, M.E.; Knoll, A.H.; Quigg, A.; Raven, J.A.; Schofield, O.; Taylor, F.J.R. The Evolution of Modern Eukaryotic Phytoplankton. Science 2004, 305, 354-360. [CrossRef]

22. De Clerck, O.; Bogaert, K.A.; Leliaert, F. Chapter Two-Diversity and Evolution of Algae: Primary Endosymbiosis. In Advances in Botanical Research; Piganeau, G., Ed.; Genomic Insights into the Biology of Algae; Academic Press: London, UK, 2012; Volume 64, pp. 55-86.

23. Blank, C.E. Origin and Early Evolution of Photosynthetic Eukaryotes in Freshwater Environments: Reinterpreting Proterozoic Paleobiology and Biogeochemical Processes in Light of Trait Evolution. J. Phycol. 2013, 49, 1040-1055. [CrossRef] [PubMed]

24. Leliaert, F.; Tronholm, A.; Lemieux, C.; Turmel, M.; DePriest, M.S.; Bhattacharya, D.; Karol, K.G.; Fredericq, S.; Zechman, F.W.; Lopez-Bautista, J.M. Chloroplast Phylogenomic Analyses Reveal the Deepest-Branching Lineage of the Chlorophyta, Palmophyllophyceae Class. Nov. Sci. Rep. 2016, 6, 25367. [CrossRef] [PubMed]

25. Lang, D.; Weiche, B.; Timmerhaus, G.; Richardt, S.; Riaño-Pachón, D.M.; Corrêa, L.G.G.; Reski, R.; Mueller-Roeber, B.; Rensing, S.A. Genome-Wide Phylogenetic Comparative Analysis of Plant Transcriptional Regulation: A Timeline of Loss, Gain, Expansion, and Correlation with Complexity. Genome Biol. Evol. 2010, 2, 488-503. [CrossRef] [PubMed]

26. Parfrey, L.W.; Lahr, D.J.G.; Knoll, A.H.; Katz, L.A. Estimating the Timing of Early Eukaryotic Diversification with Multigene Molecular Clocks. Proc. Natl. Acad. Sci. USA 2011, 108, 13624-13629. [CrossRef] [PubMed]

27. Sanderson, M.J. R8s: Inferring Absolute Rates of Molecular Evolution and Divergence Times in the Absence of a Molecular Clock. Bioinformatics 2003, 19, 301-302. [CrossRef]

28. Slapeta, J.; Lopez-Garcia, P.; Moreira, D. Global Dispersal and Ancient Cryptic Species in the Smallest Marine Eukaryotes. Mol. Biol. Evol. 2006, 23, 23-29. [CrossRef]

29. Loeblich, A.R. Protistan Phylogeny as Indicated by the Fossil Record. Taxon 1974, 23, 277-290. [CrossRef]

30. Colbath, G.K. Fossil Prasinophycean Phycomata (Chlorophyta) from the Silurian Bainbridge Formation, Missouri, U.S.A. Phycologia 1983, 22, 249-265. [CrossRef]

31. Boalch, G.; Guyohlson, D. Tasmanites, The Correct Name For Pachysphaera (Prasinophyceae, Pterospermataceae). Taxon 1992, 41, 529-531. [CrossRef]

32. Blanc-Mathieu, R.; Sanchez-Ferandin, S.; Eyre-Walker, A.; Piganeau, G. Organellar Inheritance in the Green Lineage: Insights from Ostreococcus tauri. Genome Biol. Evol. 2013, 5, 1503-1511. [CrossRef]

33. Blanc-Mathieu, R.; Krasovec, M.; Hebrard, M.; Yau, S.; Desgranges, E.; Martin, J.; Schackwitz, W.; Kuo, A.; Salin, G.; Donnadieu, C.; et al. Population Genomics of Picophytoplankton Unveils Novel Chromosome Hypervariability. Sci. Adv. 2017, 3, e1700239. [CrossRef] [PubMed]

34. Krasovec, M.; Eyre-Walker, A.; Sanchez-Ferandin, S.; Piganeau, G. Spontaneous Mutation Rate in the Smallest Photosynthetic Eukaryotes. Mol. Biol. Evol. 2017, 34, 1770-1779. [CrossRef] [PubMed]

35. Benites, L.F.; Bucchini, F.; Sanchez-Brosseau, S.; Grimsley, N.; Vandepoele, K.; Piganeau, G. Evolutionary Genomics of Sex-Related Chromosomes at the Base of the Green Lineage. Genome Biol. Evol. 2021, 13, evab216. [CrossRef] [PubMed]

36. Hanschen, E.R.; Starkenburg, S.R. The State of Algal Genome Quality and Diversity. Algal Res. 2020, 50, 101968. [CrossRef]

37. Yilmaz, S.; Singh, A.K. Single Cell Genome Sequencing. Curr. Opin. Biotechnol. 2012, 23, 437-443. [CrossRef]

38. Benites, L.F.; Poulton, N.; Labadie, K.; Sieracki, M.E.; Grimsley, N.; Piganeau, G. Single Cell Ecogenomics Reveals Mating Types of Individual Cells and SsDNA Viral Infections in the Smallest Photosynthetic Eukaryotes. Philos. Trans. R. Soc. Lond. B Biol. Sci. 2019, 374, 20190089. [CrossRef]

39. Vannier, T.; Leconte, J.; Seeleuthner, Y.; Mondy, S.; Pelletier, E.; Aury, J.-M.; de Vargas, C.; Sieracki, M.; Iudicone, D.; Vaulot, D.; et al. Survey of the Green Picoalga Bathycoccus Genomes in the Global Ocean. Sci. Rep. 2016, 6, 37900. [CrossRef]

40. Rusch, D.B.; Halpern, A.L.; Sutton, G.; Heidelberg, K.B.; Williamson, S.; Yooseph, S.; Wu, D.Y.; Eisen, J.A.; Hoffman, J.M.; Remington, K.; et al. The Sorcerer II Global Ocean Sampling Expedition: Northwest Atlantic through Eastern Tropical Pacific. PLoS. Biol. 2007, 5, 398-431. [CrossRef]

41. Piganeau, G.; Moreau, H. Screening the Sargasso Sea Metagenome for Data to Investigate Genome Evolution in Ostreococcus (Prasinophyceae, Chlorophyta). Gene 2007, 406, 184-190. [CrossRef]

42. Sunagawa, S.; Coelho, L.P.; Chaffron, S.; Kultima, J.R.; Labadie, K.; Salazar, G.; Djahanschiri, B.; Zeller, G.; Mende, D.R.; Alberti, A.; et al. Ocean Plankton. Structure and Function of the Global Ocean Microbiome. Science 2015, 348, 1261359. [CrossRef]

43. Delmont, T.O.; Gaia, M.; Hinsinger, D.D.; Fremont, P.; Vanni, C.; Guerra, A.F.; Eren, A.M.; Kourlaiev, A.; d'Agata, L.; Clayssen, Q.; et al. Functional Repertoire Convergence of Distantly Related Eukaryotic Plankton Lineages Revealed by Genome-Resolved Metagenomics. bioRxiv 2020. [CrossRef] 
44. Tragin, M.; Vaulot, D. Novel Diversity within Marine Mamiellophyceae (Chlorophyta) Unveiled by Metabarcoding. Sci. Rep. 2019, 9, 5190. [CrossRef] [PubMed]

45. Derelle, E.; Ferraz, C.; Rombauts, S.; Rouzé, P.; Worden, A.Z.; Robbens, S.; Partensky, F.; Degroeve, S.; Echeynié, S.; Cooke, R.; et al. Genome Analysis of the Smallest Free-Living Eukaryote Ostreococcus tauri Unveils Many Unique Features. Proc. Natl. Acad. Sci. USA 2006, 103, 11647-11652. [CrossRef] [PubMed]

46. Blanc-Mathieu, R.; Verhelst, B.; Derelle, E.; Rombauts, S.; Bouget, F.-Y.; Carré, I.; Château, A.; Eyre-Walker, A.; Grimsley, N.; Moreau, H.; et al. An Improved Genome of the Model Marine Alga Ostreococcus tauri Unfolds by Assessing Illumina de Novo Assemblies. BMC Genom. 2014, 15, 1103. [CrossRef]

47. Yau, S.; Krasovec, M.; Benites, L.F.; Rombauts, S.; Groussin, M.; Vancaester, E.; Aury, J.-M.; Derelle, E.; Desdevises, Y.; Escande, M.-L.; et al. Virus-Host Coexistence in Phytoplankton through the Genomic Lens. Sci. Adv. 2020, 6, eaay2587. [CrossRef]

48. Moreau, H.; Verhelst, B.; Couloux, A.; Derelle, E.; Rombauts, S.; Grimsley, N.; Van Bel, M.; Poulain, J.; Katinka, M.; HohmannMarriott, M.F.; et al. Gene Functionalities and Genome Structure in Bathycoccus prasinos Reflect Cellular Specializations at the Base of the Green Lineage. Genome Biol. 2012, 13, R74. [CrossRef]

49. Yau, S.; dos Santos, A.L.; Eikrem, W.; Ribero, C.G.; Gourvil, P.; Balzano, S.; Escande, M.-L.; Moreau, H.; Vaulot, D. Mantoniella beaufortii and Mantoniella baffinensis sp. nov. (Mamiellales, Mamiellophyceae), Two New Green Algal Species from the High Arctic. J. Phycol. 2019, 56, 37-51. [CrossRef]

50. Surek, B.; Melkonian, M. CCAC-Culture Collection of Algae at the University of Cologne: A New Collection of Axenic Algae with Emphasis on Flagellates. Nova Hedwig. 2004, 79, 77-92. [CrossRef]

51. Gachon, C.; Day, J.; Campbell, C.; Proschold, T.; Saxon, R.; Kupper, F. The Culture Collection of Algae and Protozoa (CCAP): A Biological Resource for Protistan Genomics. Gene 2007, 406, 51-57. [CrossRef]

52. Vaulot, D.; Le Gall, F.; Marie, D.; Guillou, L.; Partensky, F. The Roscoff Culture Collection (RCC): A Collection Dedicated to Marine Picoplankton. Nova Hedwig. 2004, 79, 49-70. [CrossRef]

53. Starr, R.; Zeikus, J. Utex-The Culture Collection Of Algae At The University-Of-Texas At Austin 1993 List of Cultures. J. Phycol. 1993, 29, 1-106. [CrossRef]

54. Not, F.; Siano, R.; Kooistra, W.H.C.F.; Simon, N.; Vaulot, D.; Probert, I. Chapter One-Diversity and Ecology of Eukaryotic Marine Phytoplankton. In Advances in Botanical Research; Piganeau, G., Ed.; Genomic Insights into the Biology of Algae; Academic Press: London, UK, 2012; Volume 64, pp. 1-53.

55. Shokralla, S.; Spall, J.L.; Gibson, J.F.; Hajibabaei, M. Next-Generation Sequencing Technologies for Environmental DNA Research Mol. Ecol. 2012, 21, 1794-1805. [CrossRef] [PubMed]

56. Belevich, T.A.; Milyutina, I.A.; Abyzova, G.A.; Troitsky, A.V. The Pico-Sized Mamiellophyceae and a Novel Bathycoccus Clade from the Summer Plankton of Russian Arctic Seas and Adjacent Waters. FEMS Microb. Ecol. 2021, 97, fiaa251. [CrossRef] [PubMed]

57. Monier, A.; Worden, A.Z.; Richards, T.A. Phylogenetic Diversity and Biogeography of the Mamiellophyceae Lineage of Eukaryotic Phytoplankton across the Oceans: Global Diversity of Marine Class II Prasinophytes. Environ. Microbiol. Rep. 2016, 8, 461-469. [CrossRef]

58. Ribeiro, C.G.; dos Santos, A.L.; Marie, D.; Brandini, F.P.; Vaulot, D. Small Eukaryotic Phytoplankton Communities in Tropical Waters off Brazil Are Dominated by Symbioses between Haptophyta and Nitrogen-Fixing Cyanobacteria. ISME J. 2018, 12, 1360-1374. [CrossRef]

59. Majaneva, M.; Enberg, S.; Autio, R.; Blomster, J.; Rintala, J. Mamiellophyceae Shift in Seasonal Predominance in the Baltic Sea. Aquat. Microb. Ecol. 2019, 83, 181-187. [CrossRef]

60. De Vargas, C.; Audic, S.; Henry, N.; Decelle, J.; Mahe, F.; Logares, R.; Lara, E.; Berney, C.; Le Bescot, N.; Probert, I.; et al. Eukaryotic Plankton Diversity in the Sunlit Ocean. Science 2015, 348, 1261605. [CrossRef]

61. Taib, N.; Mangot, J.-F.; Domaizon, I.; Bronner, G.; Debroas, D. Phylogenetic Affiliation of SSU RRNA Genes Generated by Massively Parallel Sequencing: New Insights into the Freshwater Protist Diversity. PLoS ONE 2013, 8, e58950. [CrossRef]

62. Piwosz, K.; Całkiewicz, J.; Gołębiewski, M.; Creer, S. Diversity and Community Composition of Pico- and Nanoplanktonic Protists in the Vistula River Estuary (Gulf of Gdańsk, Baltic Sea). Estuar. Coast. Shelf Sci. 2018, 207, 242-249. [CrossRef]

63. Choi, D.H.; An, S.M.; Chun, S.; Yang, E.C.; Selph, K.E.; Lee, C.M.; Noh, J.H. Dynamic Changes in the Composition of Photosynthetic Picoeukaryotes in the Northwestern Pacific Ocean Revealed by High-Throughput Tag Sequencing of Plastid 16S RRNA Genes. FEMS Microbiol. Ecol. 2016, 92, fiv170. [CrossRef]

64. Simmons, M.P.; Bachy, C.; Sudek, S.; van Baren, M.J.; Sudek, L.; Ares, M., Jr.; Worden, A.Z. Intron Invasions Trace Algal Speciation and Reveal Nearly Identical Arctic and Antarctic Micromonas Populations. Mol. Biol. Evol. 2015, 32, 2219-2235. [CrossRef] [PubMed]

65. Dela Peña, L.B.R.O.; Tejada, A.J.P.; Quijano, J.B.; Alonzo, K.H.; Gernato, E.G.; Caril, A.; Dela Cruz, M.A.M.; Onda, D.F.L. Diversity of Marine Eukaryotic Picophytoplankton Communities with Emphasis on Mamiellophyceae in Northwestern Philippines. Philipp. J. Sci. 2021, 150, 27-42.

66. Pearman, J.K.; Kürten, S.; Sarma, Y.V.B.; Jones, B.H.; Carvalho, S. Biodiversity Patterns of Plankton Assemblages at the Extremes of the Red Sea. FEMS Microbiol. Ecol. 2016, 92, fiw002. [CrossRef] [PubMed]

67. Zhang, F.; Cao, S.; Gao, Y.; He, J. Distribution and Environmental Correlations of Picoeukaryotes in an Arctic Fjord (Kongsfjorden, Svalbard) during the Summer. Polar Res. 2019, 38, 3390. [CrossRef] 
68. SILVA Ribosomal RNA Gene Database Project: Improved Data Processing and Web-Based Tools | Nucleic Acids Research I Oxford Academic. Available online: https:/ / academic.oup.com/nar/article/41/D1/D590/1069277 (accessed on 9 November 2021).

69. Guillou, L.; Bachar, D.; Audic, S.; Bass, D.; Berney, C.; Bittner, L.; Boutte, C.; Burgaud, G.; de Vargas, C.; Decelle, J.; et al. The Protist Ribosomal Reference Database (PR2): A Catalog of Unicellular Eukaryote Small Sub-Unit RRNA Sequences with Curated Taxonomy. Nucleic Acids Res. 2013, 41, D597-D604. [CrossRef] [PubMed]

70. Bradley, I.M.; Pinto, A.J.; Guest, J.S. Design and Evaluation of Illumina MiSeq-Compatible, 18S RRNA Gene-Specific Primers for Improved Characterization of Mixed Phototrophic Communities. Appl. Environ. Microbiol. 2016, 82, 5878-5891. [CrossRef]

71. Tragin, M.; Zingone, A.; Vaulot, D. Comparison of Coastal Phytoplankton Composition Estimated from the V4 and V9 Regions of the 18S RRNA Gene with a Focus on Photosynthetic Groups and Especially Chlorophyta. Environ. Microbiol. 2018, 20, 506-520. [CrossRef]

72. Leconte, J.; Benites, L.F.; Vannier, T.; Wincker, P.; Piganeau, G.; Jaillon, O. Genome Resolved Biogeography of Mamiellales. Genes 2020, 11, 66. [CrossRef]

73. Cottrell, M.T.; Suttle, C.A. Wide-Spread Occurrence and Clonal Variation in Viruses Which Cause Lysis of a Cosmopolitan, Eukaryotic Marine Phytoplankter, Micromonas pusilla. Mar. Ecol. Prog. Ser. 1991, 78, 1-9. [CrossRef]

74. Mayer, J.A.; Taylor, F.J.R. A Virus Which Lyses the Marine Nanoflagellate Micromonas pusilla. Nature 1979, 281, 299-301. [CrossRef]

75. Evans, C.; Archer, S.D.; Jacquet, S.; Wilson, W.H. Direct Estimates of the Contribution of Viral Lysis and Microzooplankton Grazing to the Decline of a Micromonas spp. Population. Aquat. Microb. Ecol. 2003, 30, 207-219. [CrossRef]

76. Cottrell, M.T.; Suttle, C.A. Dynamics of Lytic Virus Infecting the Photosynthetic Marine Picoflagellate Micromonas pusilla. Limnol. Oceanogr. 1995, 40, 730-739. [CrossRef]

77. Hingamp, P.; Grimsley, N.; Acinas, S.G.; Clerissi, C.; Subirana, L.; Poulain, J.; Ferrera, I.; Sarmento, H.; Villar, E.; Lima-Mendez, G.; et al. Exploring Nucleo-Cytoplasmic Large DNA Viruses in Tara Oceans Microbial Metagenomes. ISME J. 2013, 7, $1678-1695$. [CrossRef] [PubMed]

78. Schulz, F.; Roux, S.; Paez-Espino, D.; Jungbluth, S.; Walsh, D.A.; Denef, V.J.; McMahon, K.D.; Konstantinidis, K.T.; Eloe-Fadrosh, E.A.; Kyrpides, N.C.; et al. Giant Virus Diversity and Host Interactions through Global Metagenomics. Nature 2020, 578, 432-436. [CrossRef] [PubMed]

79. Pringle, C.R. Virus Taxonomy-San Diego 1998. Arch. Virol. 1998, 143, 1449-1459. [CrossRef]

80. Short, S.M. The Ecology of Viruses That Infect Eukaryotic Algae. Environ. Microbiol. 2012, 14, 2253-2271. [CrossRef]

81. Bellec, L.; Grimsley, N.; Moreau, H.; Desdevises, Y. Phylogenetic Analysis of New Prasinoviruses (Phycodnaviridae) That Infect the Green Unicellular Algae Ostreococcus, Bathycoccus and Micromonas. Environ. Microbiol. Rep. 2009, 1, 114-123. [CrossRef]

82. Moreau, H.; Piganeau, G.; Desdevises, Y.; Cooke, R.; Derelle, E.; Grimsley, N. Marine Prasinovirus Genomes Show Low Evolutionary Divergence and Acquisition of Protein Metabolism Genes by Horizontal Gene Transfer. J. Virol. 2010, 84, 12555-12563. [CrossRef]

83. Martínez, J.M.; Boere, A.; Gilg, I.; van Lent, J.W.M.; Witte, H.J.; van Bleijswijk, J.D.L.; Brussaard, C.P.D. New Lipid EnvelopeContaining DsDNA Virus Isolates Infecting Micromonas pusilla Reveal a Separate Phylogenetic Group. Aquat. Microb. Ecol. 2015, 74, 17-28. [CrossRef]

84. Baudoux, A.-C.; Lebredonchel, H.; Dehmer, H.; Latimier, M.; Edern, R.; Rigaut-Jalabert, F.; Ge, P.; Guillou, L.; Foulon, E.; Bozec, Y.; et al. Interplay between the Genetic Clades of Micromonas and Their Viruses in the Western English Channel. Environ. Microbiol. Rep. 2015, 7, 765-773. [CrossRef]

85. Zingone, A.; Natale, F.; Biffali, E.; Borra, M.; Forlani, G.; Sarno, D. Diversity in Morphology, Infectivity, Molecular Characteristics and Induced Host Resistance between Two Viruses Infecting Micromonas pusilla. Aquat. Microb. Ecol. 2006, 45, 1-14. [CrossRef]

86. Maat, D.S.; Biggs, T.; Evans, C.; Van Bleijswijk, J.D.L.; Van der Wel, N.N.; Dutilh, B.E.; Brussaard, C.P.D. Characterization and Temperature Dependence of Arctic Micromonas polaris Viruses. Viruses 2017, 9, 134. [CrossRef] [PubMed]

87. Bellec, L.; Clerissi, C.; Edern, R.; Foulon, E.; Simon, N.; Grimsley, N.; Desdevises, Y. Cophylogenetic Interactions between Marine Viruses and Eukaryotic Picophytoplankton. BMC Evol. Biol. 2014, 14, 59. [CrossRef] [PubMed]

88. Bellec, L.; Grimsley, N.; Desdevises, Y. Isolation of Prasinoviruses of the Green Unicellular Algae Ostreococcus spp. on a Worldwide Geographical Scale. Appl. Environ. Microbiol. 2010, 76, 96-101. [CrossRef]

89. Derelle, E.; Monier, A.; Cooke, R.; Worden, A.Z.; Grimsley, N.H.; Moreau, H. Diversity of Viruses Infecting the Green Microalga Ostreococcus lucimarinus. J. Virol. 2015, 89, 5812-5821. [CrossRef]

90. Weynberg, K.D.; Allen, M.J.; Gilg, I.C.; Scanlan, D.J.; Wilson, W.H. Genome Sequence of Ostreococcus tauri Virus OtV-2 Throws Light on the Role of Picoeukaryote Niche Separation in the Ocean. J. Virol. 2011, 85, 4520-4529. [CrossRef]

91. Derelle, E.; Ferraz, C.; Escande, M.-L.; Eychenié, S.; Cooke, R.; Piganeau, G.; Desdevises, Y.; Bellec, L.; Moreau, H.; Grimsley, N. Life-Cycle and Genome of OtV5, a Large DNA Virus of the Pelagic Marine Unicellular Green Alga Ostreococcus tauri. PLoS ONE 2008, 3, e2250. [CrossRef]

92. Weynberg, K.D.; Allen, M.J.; Ashelford, K.; Scanlan, D.J.; Wilson, W.H. From Small Hosts Come Big Viruses: The Complete Genome of a Second Ostreococcus tauri Virus, OtV-1. Environ. Microbiol. 2009, 11, 2821-2839. [CrossRef]

93. Bellec, L.; Grimsley, N.; Derelle, E.; Moreau, H.; Desdevises, Y. Abundance, Spatial Distribution and Genetic Diversity of Ostreococcus tauri Viruses in Two Different Environments. Environ. Microbiol. Rep. 2010, 2, 313-321. [CrossRef] 
94. Clerissi, C.; Grimsley, N.; Ogata, H.; Hingamp, P.; Poulain, J.; Desdevises, Y. Unveiling of the Diversity of Prasinoviruses (Phycodnaviridae) in Marine Samples by Using High-Throughput Sequencing Analyses of PCR-Amplified DNA Polymerase and Major Capsid Protein Genes. Appl. Environ. Microbiol. 2014, 80, 3150-3160. [CrossRef]

95. Aylward, F.O.; Moniruzzaman, M.; Ha, A.D.; Koonin, E.V. A Phylogenomic Framework for Charting the Diversity and Evolution of Giant Viruses. bioRxiv 2021. [CrossRef]

96. Katoh, K.; Standley, D.M. MAFFT Multiple Sequence Alignment Software Version 7: Improvements in Performance and Usability. Mol. Biol. Evol. 2013, 30, 772-780. [CrossRef] [PubMed]

97. Lemoine, F.; Gascuel, O. Gotree/Goalign: Toolkit and Go API to Facilitate the Development of Phylogenetic Workflows. bioRxiv 2021. [CrossRef]

98. Minh, B.Q.; Schmidt, H.A.; Chernomor, O.; Schrempf, D.; Woodhams, M.D.; von Haeseler, A.; Lanfear, R. IQ-TREE 2: New Models and Efficient Methods for Phylogenetic Inference in the Genomic Era. Mol. Biol. Evol. 2020, 37, 1530-1534. [CrossRef]

99. Letunic, I.; Bork, P. Interactive Tree of Life (ITOL) v3: An Online Tool for the Display and Annotation of Phylogenetic and Other Trees. Nucleic Acids Res. 2016, 44, W242-W245. [CrossRef] [PubMed]

100. Brussaard, C.P.D.; Noordeloos, A.A.M.; Sandaa, R.-A.; Heldal, M.; Bratbak, G. Discovery of a DsRNA Virus Infecting the Marine Photosynthetic Protist Micromonas pusilla. Virology 2004, 319, 280-291. [CrossRef] [PubMed]

101. Sahlsten, E. Seasonal Abundance in Skagerrak-Kattegat Coastal Waters and Host Specificity of Viruses Infecting the Marine Photosynthetic Flagellate Micromonas pusilla. Aquat. Microb. Ecol. 1998, 16, 103-108. [CrossRef]

102. Clerissi, C.; Desdevises, Y.; Grimsley, N. Prasinoviruses of the Marine Green Alga Ostreococcus tauri Are Mainly Species Specific. J. Virol. 2012, 86, 4611-4619. [CrossRef]

103. Chen, H.; Zhang, W.; Li, X.; Pan, Y.; Yan, S.; Wang, Y. The Genome of a Prasinoviruses-Related Freshwater Virus Reveals Unusual Diversity of Phycodnaviruses. BMC Genom. 2018, 19, 49. [CrossRef]

104. Xu, S.; Zhou, L.; Liang, X.; Zhou, Y.; Chen, H.; Yan, S.; Wang, Y. Novel Cell-Virus-Virophage Tripartite Infection Systems Discovered in the Freshwater Lake Dishui Lake in Shanghai, China. J. Virol. 2020, 94, e00149-20. [CrossRef]

105. Zhang, W.; Zhou, J.; Liu, T.; Yu, Y.; Pan, Y.; Yan, S.; Wang, Y. Four Novel Algal Virus Genomes Discovered from Yellowstone Lake Metagenomes. Sci. Rep. 2015, 5, 15131. [CrossRef] [PubMed]

106. Zingone, A.; Sarno, D.; Forlani, G. Seasonal Dynamics in the Abundance of Micromonas pusilla (Prasinophyceae) and Its Viruses in the Gulf of Naples (Mediterranean Sea). J. Plankton Res. 1999, 21, 2143-2159. [CrossRef]

107. Meng, L.; Endo, H.; Blanc-Mathieu, R.; Chaffron, S.; Hernández-Velázquez, R.; Kaneko, H.; Ogata, H. Quantitative Assessment of NCLDV-Host Interactions Predicted by Co-Occurrence Analyses. bioRxiv 2021. [CrossRef]

108. Endo, H.; Blanc-Mathieu, R.; Li, Y.; Salazar, G.; Henry, N.; Labadie, K.; de Vargas, C.; Sullivan, M.B.; Bowler, C.; Wincker, P.; et al. Biogeography of Marine Giant Viruses Reveals Their Interplay with Eukaryotes and Ecological Functions. Nat. Ecol. Evol. 2020, 4, 1639-1649. [CrossRef] [PubMed]

109. Kaneko, H.; Blanc-Mathieu, R.; Endo, H.; Chaffron, S.; Delmont, T.O.; Gaia, M.; Henry, N.; Hernández-Velázquez, R.; Nguyen, C.H.; Mamitsuka, H.; et al. Eukaryotic Virus Composition Can Predict the Efficiency of Carbon Export in the Global Ocean. iScience 2021, 24, 102002. [CrossRef] [PubMed]

110. Castillo, Y.M.; Forn, I.; Yau, S.; Morán, X.A.G.; Alonso-Sáez, L.; Arandia-Gorostidi, N.; Vaqué, D.; Sebastián, M. Seasonal Dynamics of Natural Ostreococcus Viral Infection at the Single Cell Level Using VirusFISH. Environ. Microbiol. 2021, 23, 3009-3019. [CrossRef]

111. Xie, H.; Yang, C.; Sun, Y.; Igarashi, Y.; Jin, T.; Luo, F. PacBio Long Reads Improve Metagenomic Assemblies, Gene Catalogs, and Genome Binning. Front. Genet. 2020, 11, 1077. [CrossRef]

112. Priest, T.; Orellana, L.H.; Huettel, B.; Fuchs, B.M.; Amann, R. Microbial Metagenome-Assembled Genomes of the Fram Strait from Short and Long Read Sequencing Platforms. PeerJ 2021, 9, e11721. [CrossRef]

113. Marbouty, M.; Cournac, A.; Flot, J.-F.; Marie-Nelly, H.; Mozziconacci, J.; Koszul, R. Metagenomic Chromosome Conformation Capture (Meta3C) Unveils the Diversity of Chromosome Organization in Microorganisms. eLife 2014, 3, e03318. [CrossRef]

114. DeMaere, M.Z.; Darling, A.E. Bin3C: Exploiting Hi-C Sequencing Data to Accurately Resolve Metagenome-Assembled Genomes. Genome Biol. 2019, 20, 46. [CrossRef]

115. Burton, J.N.; Liachko, I.; Dunham, M.J.; Shendure, J. Species-Level Deconvolution of Metagenome Assemblies with Hi-C-Based Contact Probability Maps. G3 Genes I Genomes I Genetics 2014, 4, 1339-1346. [CrossRef]

116. Tao, Y.; Gao, P.; Li, B.; Xing, P.; Wu, Q.L. Tracking Double-Stranded DNA Bacteriophages and Their Hosts in a Deep Freshwater Lake by Integrating Metagenomics and The Hi-C Technique. Res. Sq. Prepr. 2020. [CrossRef]

117. Bickhart, D.M.; Watson, M.; Koren, S.; Panke-Buisse, K.; Cersosimo, L.M.; Press, M.O.; Van Tassell, C.P.; Van Kessel, J.A.S.; Haley, B.J.; Kim, S.W.; et al. Assignment of Virus and Antimicrobial Resistance Genes to Microbial Hosts in a Complex Microbial Community by Combined Long-Read Assembly and Proximity Ligation. Genome Biol. 2019, 20, 153. [CrossRef] [PubMed]

118. Ignacio-Espinoza, J.C.; Laperriere, S.M.; Yeh, Y.-C.; Weissman, J.; Hou, S.; Long, A.M.; Fuhrman, J.A. Ribosome-Linked mRNArRNA Chimeras Reveal Active Novel Virus Host Associations. bioRxiv 2020. [CrossRef]

119. Moran, M.A.; Satinsky, B.; Gifford, S.M.; Luo, H.; Rivers, A.; Chan, L.-K.; Meng, J.; Durham, B.P.; Shen, C.; Varaljay, V.A.; et al. Sizing up Metatranscriptomics. ISME J. 2013, 7, 237-243. [CrossRef]

120. Ji, N.; Lin, L.; Li, L.; Yu, L.; Zhang, Y.; Luo, H.; Li, M.; Shi, X.; Wang, D.-Z.; Lin, S. Metatranscriptome Analysis Reveals Environmental and Diel Regulation of a Heterosigma Akashiwo (Raphidophyceae) Bloom. Environ. Microbiol. 2018, 20, 1078-1094. [CrossRef] 
121. Lampe, R.H.; Cohen, N.R.; Ellis, K.A.; Bruland, K.W.; Maldonado, M.T.; Peterson, T.D.; Till, C.P.; Brzezinski, M.A.; Bargu, S.; Thamatrakoln, K.; et al. Divergent Gene Expression among Phytoplankton Taxa in Response to Upwelling. Environ. Microbiol. 2018, 20, 3069-3082. [CrossRef]

122. Salazar, G.; Paoli, L.; Alberti, A.; Huerta-Cepas, J.; Ruscheweyh, H.-J.; Cuenca, M.; Field, C.M.; Coelho, L.P.; Cruaud, C.; Engelen, S.; et al. Gene Expression Changes and Community Turnover Differentially Shape the Global Ocean Metatranscriptome. Cell 2019, 179, 1068-1083.e21. [CrossRef] 